\title{
Modified Unit Cell Approach for Modelling Geosynthetic-Reinforced
} Column-Supported Embankments

\author{
Yan $\mathrm{Yu}^{1}$, Richard J. Bathurst ${ }^{2}$ and Ivan P. Damians ${ }^{3}$ \\ 1. Postdoctoral Fellow, GeoEngineering Centre at Queen's-RMC, Department of Civil \\ Engineering, Royal Military College of Canada Kingston, Ontario K7K 7B4, Canada; Phone: \\ (+1) 6135416000 ext. 6347, Fax: (+1) 613541 6218, E-mail: yan.yu@queensu.ca \\ (corresponding author) \\ 2. Professor, GeoEngineering Centre at Queen's-RMC, Department of Civil Engineering, Royal \\ Military College of Canada Kingston, Ontario K7K 7B4, Canada; Phone: (+1) 6135416000 \\ ext. 6479, Fax: (+1) 6135416218 , E-mail: bathurst-r@,rmc.ca
}

3. Ph.D. Candidate, Department of Geotechnical Engineering and Geo-Sciences (ETCG) and Institute for Sustainability (IS.UPC). Universitat Politècnica de Catalunya-BarcelonaTech (UPC), Spain; Phone: (+34) 93401 1695, Fax: (+34) 93401 7251, E-mail: ivan.puig@upc.edu

Abstract: Geosynthetic-reinforced and column-supported (GRCS) embankments have proven to be an effective construction technique for fills on soft foundations. The paper introduces a modified unit cell approach to model GRCS embankments supported by deep mixed column walls. The modified unit cells include linear elastic springs at one or both vertical boundaries to simulate lateral displacements of the embankment fill and foundation soil. Program FLAC is used to compare numerical outcomes using the modified unit cells with those using the typical unit cell arrangement with lateral rigid side boundaries. Numerical results demonstrate good agreement between simulations using small-strain and large-strain modes in some cases and large differences in other cases. Lateral displacements of the embankment fill and foundation soil using the modified unit cells are shown to have large influence on reinforcement loads. Finally the paper demonstrates that calculated reinforcement loads are sensitive to choice of small-strain or large-strain mode when using program FLAC. 
31 Key Words: Column-supported embankments, numerical modelling, unit cell, deep mixing, 32 geosynthetic reinforcement, FLAC

\section{Introduction}

Embankments over soft foundations must be designed to avoid bearing capacity failure of the foundation, unacceptable lateral spreading of the embankment fill, and damage to adjacent structures due to large differential settlements. An effective technique to overcome these challenges is to use geosynthetic-reinforced and column-supported (GRCS) embankments (Figure 1). Common support types for GRCS embankments are cement-soil deep mixing (DM) columns (e.g., Bergado et al. 1999; Borges and Marques 2011; Bruce et al. 2013; Chai et al. 2015; Forsman et al. 1999; Han et al. 2007; Huang and Han 2009, 2010; Huang et al. 2009; columns (e.g., Hosseinpour et al. 2015; Khabbazian et al. 2015; Yoo 2010). Concrete and timber piles with and without pile caps and basal reinforcement have also been used to increase the construction rate and to improve load transfer from the soft soil to the stiffer piles (e.g., Briançon and Simon 2012; Liu et al. 2007; Nunez et al. 2013; Rowe and Liu 2015; Zhang et al. 2013).

GRCS embankments can be designed using close-form solutions that take advantage of soil arching and tensioned membrane load transfer mechanisms within the GRCS embankment system (e.g., Hewlett and Randolph 1988; BS8006 2010; EBGEO 2011; Kempfert et al. 2004; Van Eekelen et al. 2011). Advanced numerical models using the finite element method (FEM) and finite difference method (FDM) are becoming more common as a research tool to improve understanding of the behaviour of GRCS embankments (e.g., Liu and Rowe 2015; Han et al. 2007). The advantage of using a full-width numerical model of a GRCS embankment is that lateral deformations that vary across the width and depth of the embankment fill and foundation are predicted. Of course, the accuracy of numerical predictions will depend on mesh refinement and the complexity of the constitutive models used for the component materials and

60 their interfaces. However, parametric analyses at the design stage using a full-width model can 61 be very time consuming and may not adequately capture local load transfer mechanisms 
62 particularly if a coarse numerical mesh is used in the simulations. A strategy to overcome this

63 shortcoming is the unit cell approach used by many researchers (e.g., Han and Gabr 2002;

64 Smith and Filz 2007; Khabbazian et al. 2015). The location of an example unit cell in a GRCS

65 embankment is shown in Figure 1. However, there are also limitations associated with typical

66 unit cells including the use of fixed lateral boundaries (Figure 2a). Using both a unit cell and a

67 full-width numerical model for a GRCS embankment, Khabbazian et al. (2015) showed that the

68 tensile loads in the geosynthetic reinforcement using the full-width model were much greater

69 than those using the unit cell approach for the same structure. They attributed this discrepancy to

70 lateral spreading of the embankment fill and foundation soil in the full-width model that was not

71 captured by the unit cell. Regardless of which approach is used to model GRCS embankment

72 performance, numerical results can also depend on how geometric nonlinearity of the soil and

73 reinforcement is modelled using the small-strain and large-strain options in FDM program FLAC

74 (Itasca 2011) or with and without mesh updating in FEM software programs.

76 The objectives of this paper are to demonstrate a new modelling technique using a modified unit

77 cell approach to simulate the lateral spreading of the embankment fill and foundation soil, and to

78 examine the influence of large-strain and small-strain model options in program FLAC on

79 numerical outcomes (i.e., with and without mesh updating during calculation steps). Numerical

80 results using (conventional) unit cells with lateral rigid boundaries and units cells with one or

81 both vertical boundaries supported by horizontal linear elastic springs are presented and

82 compared. The effect of lateral spring stiffness values on lateral spreading of the embankment

83 fill and foundation soil, and reinforcement loads are demonstrated.

87 Numerical analyses using FLAC models (Itasca 2011) can be executed in either large-strain 88 mode (based on the Lagrangian formulation) or small-strain mode (based on the Eulerian 89 formulation). For the Lagrangian formulation, the numerical grid coordinates at the end of each 90 calculation step (or specified steps) are updated by adding the grid incremental displacements to 91 grid coordinates before the next step. Hence, stresses and displacements at the current calculation 92 step are calculated based on the updated grid representing the deformed material zones. However 
93 for the Eulerian formulation, the grid is fixed to the original geometry and material zones. The

94 calculation of stresses and displacements is based on the fixed grid even though the material 95 zones move and deform during subsequent calculation steps. The reader is directed to the FLAC 96 manual (Itasca 2011) for details regarding small- and large-strain options in the program.

\section{Problem Definition and Parameter Values}

Figure 1 shows a GRCS embankment where the soft foundation soil is improved by the cementsoil DM column walls. The numerical simulations carried out in this paper are for twodimensional cases because of the plane-strain condition associated with Figure 1. However, the general approach presented in this paper can be extended to model three-dimensional GRCS embankment cases. This paper uses the example of GRCS embankments with 10-m thick soft foundation soil and 1- to 5-m thick embankment fills. Above the soft foundation soil is a working platform fill with a geosynthetic layer placed $0.3 \mathrm{~m}$ above the foundation soil surface.

107 The spacing of 0.7-m thick column walls was $2.8 \mathrm{~m}$ (e.g., Forsman et al. 1999; Han et al. 2007; Huang and Han 2010). The column walls are founded on bedrock.

The location of an example unit cell in this study is shown in Figure 1. Figure 2a shows a unit cell (Case 1) with typical boundary conditions (e.g., fixed $y$-direction at bottom of the cell, and

112 fixed $x$-displacement at both left and right sides of the cell). The width of the unit cell is $2.8 \mathrm{~m}$ 113 with half of the DM column wall (i.e., 0.35-m thick) on both right and left sides of the unit cell.

114 To allow for lateral spreading of the embankment fill and foundation soil, the Case 1 unit cell is 115 first modified using a column of horizontal springs (with axial stiffness $k$ ) at the right side 116 boundary of both the embankment fill and foundation soil (Case 2 - Figures $\mathbf{2 b}$ ) and then both 117 left and right side boundaries (Case 3 - Figure 2c). The spring stiffness values can be different 118 on left and right sides of the unit cell and different for the embankment fill and soft foundation 119 soil. These cases are also examined in the paper.

121 For a 5-m high embankment fill, the unit cell was modelled using 8400 zones and 112 cable 122 elements for the geosynthetic reinforcement. A linear elastic model with a Mohr-Coulomb 123 failure criterion was selected to model both embankment fill and soft foundation soil. More 
124 advanced constitutive models for the soils and reinforcement were not used in this study in order

125 to focus on the modified unit cell concept. Parameter values are summarized in Table $\mathbf{1}$ and were 126 selected based on ranges reported in the literature. The material properties for the working 127 platform fill were taken to be the same as those for the embankment fill. A depth-dependent 128 Young's modulus for the foundation soil was used as follows: $E_{\mathrm{fs}, 1}=0.5 \mathrm{MPa}$ for foundation soil 129 depth between 0 and $2 \mathrm{~m}, E_{\mathrm{fs}, 2}=1 \mathrm{MPa}$ between 2 and $4 \mathrm{~m}, E_{\mathrm{fs}, 3}=1.5 \mathrm{MPa}$ between 4 and $6 \mathrm{~m}$, $130 E_{\mathrm{fs}, 4}=2 \mathrm{MPa}$ between 6 and $8 \mathrm{~m}$, and $E_{\mathrm{fs}, 5}=2.5 \mathrm{MPa}$ between 8 and $10 \mathrm{~m}$. A linear elastic model 131 was used for the DM column walls.

133 The load transfer between the dissimilar materials within the unit cell was modelled using 134 interfaces with the normal stiffness, shear stiffness, friction angle, dilation angle and cohesion 135 values shown in Table 2 together with a strength reduction factor of $R_{\mathrm{i}}=2 / 3$. The method to 136 calculate the interface parameter values based on the surrounding soil properties is described by 137 Yu et al. (2015).

The lateral springs shown in Figure $\mathbf{2 b}$ and $\mathbf{2 c}$ were modelled using special interfaces with only 140 normal stiffness values (the shear stiffness values were set to zero) using the 'glued' condition in 141 FLAC. Thus for these interfaces, friction angle, dilation angle, and cohesion values were not 142 required. The concept of using horizontal springs to simulate the soil lateral response in this 143 paper is similar to that used in soil-structure interaction design of supported excavation walls and 144 analyses for laterally loaded piles (e.g., Canadian Geotechnical Society 2006).

146 The cable nodes for the geosynthetic reinforcement on the left and right side of the unit cell were 147 defined using grid numbers and the remainder was defined using $x$ - and $y$-coordinates. The 148 geosynthetic reinforcement was assigned an axial stiffness of $J=2000 \mathrm{kN} / \mathrm{m}$. This value falls 149 within measured ranges reported by Forsman et al. (1999) and is similar to the value used in 150 numerical models by Han et al. (2007) and Huang and Han (2010). The cable elements have a 151 cross-section area of $A_{\mathrm{g}}=0.002 \mathrm{~m}^{2}$ and perimeter of $P_{\mathrm{g}}=2 \mathrm{~m}$ (with an out-of-plane width of 1 $152 \mathrm{~m})$. Thus the Young's modulus of each cable element is calculated as $E_{\mathrm{g}}=J / A_{\mathrm{g}}=2000 / 0.002=$ $1531000 \mathrm{MPa}$. For the cable grout properties, the shear stiffness is $K_{\mathrm{s}, \mathrm{g}}=P_{\mathrm{g}} \times k_{\mathrm{s}, \mathrm{pf}}=2 \times 10=20$ 
$154 \mathrm{MN} / \mathrm{m} / \mathrm{m}$, the adhesion is $C_{\mathrm{g}}=P_{\mathrm{g}} \times c_{\mathrm{i}, \mathrm{pf}}=2 \times 0.67=1.33 \mathrm{kPa}$, and the friction angle is $\phi_{\mathrm{g}}=\phi_{\mathrm{i}, \mathrm{pf}}=$ $15525^{\circ}$. Table 3 summarizes all properties related to the cable elements.

157 The modelling started by setting the initial ground stresses using $K_{0}=1-\sin \left(\phi_{\mathrm{fs}}\right)=0.741$ for the 158 soft foundation soil without the DM column walls (e.g., by assuming that the DM column walls 159 have the same material properties as the soft foundation soil). To simulate the DM column walls, 160 the true wall material properties were then applied and the model was solved to equilibrium. The 161 influence of installing the DM column wall on the stress distribution within the soft foundation 162 soil was not considered in this paper. The numerical grid displacements and velocities were then 163 set to zero. Small-strain mode was used in all simulations prior to placement of the fill. 164 Thereafter, during embankment construction, small-strain or large-strain mode was selected to 165 investigate the influence of strain mode on numerical outcomes. To simulate the embankment 166 construction, $0.2-\mathrm{m}$ thick embankment fill lifts were activated in sequence and the model was 167 solved to equilibrium for each embankment fill lift until reaching the final embankment height of

$1685 \mathrm{~m}$. The activation of the second embankment fill lift was accompanied by adding the cable 169 elements to the model. It should be noted that only idealized conditions for the foundation soil 170 were examined in this study; hence the generation and dissipation of pore-water pressures that 171 may occur in field cases was not considered.

\section{Results}

\subsection{Unit Cell for Case 1}

177 Figure 3a shows the calculated maximum vertical stresses at the foundation surface using a unit 178 cell with fixed $x$-displacement at both right and left sides of the unit cell (Case 1; Figure 2a). 179 The numerical results show that increasing the embankment fill height increased the maximum 180 vertical stress at the foundation surface. For example, the maximum foundation surface vertical 181 stress was about $14 \mathrm{kPa}$ for $1-\mathrm{m}$ high embankment fill and increased to about $22 \mathrm{kPa}$ for 5-m 182 high embankment fill when using the large-strain mode. The differences in calculated maximum 183 vertical stresses at the foundation surface using both large- and small-strain modes are negligible. 184 However, for the embankment fill higher than $0.5 \mathrm{~m}$, the calculated maximum vertical stresses at 
185 the foundation surface were much less than those calculated using only soil self-weight $\left(\gamma_{\mathrm{ef}} h\right)$ 186 because of the soil arching effect. The greater vertical stress at the foundation surface with

187 increasing embankment height resulted in larger vertical settlement as shown in Figure 3b. The 188 maximum settlement at the foundation surface was about $44 \mathrm{~mm}$ at $1-\mathrm{m}$ high embankment fill 189 and increased to about $85 \mathrm{~mm}$ at 5-m high embankment fill when using large-strain mode. The 190 differences in vertical settlements at the foundation surface using large- and small-strain modes 191 were less than $3 \mathrm{~mm}$ for the Case 1 unit cell examined in this paper.

193 The load transfer from the embankment fill to the DM column walls and soft foundation soil was 194 modelled using interfaces. Figure 4a shows the interface normal stresses acting on the DM 195 column wall top and foundation surface at 5-m high embankment fill for the Case 1 unit cell 196 (Figure 2a). The vertical stresses on the soft foundation surface (i.e., on the center part of the 197 unit cell) were much lower than those at the top of the DM column walls (i.e., left and right sides 198 of the unit cell) because the soil self-weight load above the soft foundation is transferred to the 199 DM column walls due to the soil arching effect. For example, the vertical stresses at the centers 200 of the DM column walls (i.e., left and right edges of the unit cell) were about $332 \mathrm{kPa}$ and 201 increased to about $388 \mathrm{kPa}$ at the intersections between the $\mathrm{DM}$ column walls and foundation 202 soil when using large-strain mode and are much greater than those computed based on soil self203 weight alone (i.e., $100 \mathrm{kPa}$ ). The vertical stresses on the foundation surface were generally less 204 than $24 \mathrm{kPa}$ which are much lower than stresses due to soil self-weight. The choice of large- and 205 small-strain mode had negligible influence on the vertical stresses at the foundation surface and 206 the top of the DM column walls using the Case 1 unit cell.

208 The soil arching effect can also be appreciated from the vertical stresses at the center of the unit 209 cell within the 5-m high embankment fill shown in Figure $\mathbf{4 b}$. The calculated vertical stresses 210 within the embankment fill were equal to those from soil self-weight over the first $2 \mathrm{~m}$ below the 211 embankment surface. Thereafter, the calculated vertical stress plots depart from the soil self212 weight line because of the stress redistribution within the embankment fill due to soil arching.

214 Figure 5 shows the reinforcement tensile loads for the 5-m high embankment fill and Case 1 unit 215 cell (Figure 2a) using both small- and large-strain modes in FLAC. The use of large-strain mode 
216 resulted in reinforcement tensile loads of about $8 \mathrm{kN} / \mathrm{m}$ at $x=0$ and $2.8 \mathrm{~m}$, maximum values of

$21711 \mathrm{kN} / \mathrm{m}$ at $x=0.35$ and $2.45 \mathrm{~m}$, and minimum value of $1.6 \mathrm{kN} / \mathrm{m}$ at $x=1.4 \mathrm{~m}$. However, when

218 using the small-strain mode the reinforcement tensile loads were much lower (e.g., the maximum

219 reinforcement load was about $3 \mathrm{kN} / \mathrm{m}$ at $x=0$ and $2.8 \mathrm{~m}$ for the small-strain mode versus 11

$220 \mathrm{kN} / \mathrm{m}$ at $x=0.35$ and $2.45 \mathrm{~m}$ noted above for the large-strain mode). The influence of choice of 221 small- and large-strain mode in FLAC on the magnitude of reinforcement tensile loads is judged

222 to be significant for the Case 1 unit cell conditions. The differences are because the 223 reinforcement tensile loads using the large-strain mode (i.e., with mesh updating) were generated

224 from both the horizontal and vertical differential displacements between the soil and the 225 reinforcement, while those using small-strain mode (i.e., without mesh updating) were generated 226 only from the horizontal differential displacements between the soil and the reinforcement.

\subsection{Unit Cell for Case 2}

The results presented thus far are for the Case 1 unit cell (Figure 2a) with typical boundary conditions which do not account for lateral spreading of embankment fill and soft foundation soil. This section examines the first of two modified unit cells proposed in this paper where the

233 left side of the cell is fixed in $x$-direction and the right side of the unit cell is supported by a

234 series of horizontal springs (Case 2 in Figure 2b). To simplify the numerical analysis, only 235 linear elastic springs are considered.

237 Figure 6a shows the maximum vertical stresses at the foundation surface for the Case 2 unit cell with a spring stiffness value of $k=1 \mathrm{MPa} / \mathrm{m}$ using both large- and small-strain modes. For this example the spring stiffness values for the embankment fill and the soft foundation soil were the same. The modelling results show that the maximum vertical stresses at the foundation surface were higher than those for the Case 1 unit cell example in Figure 3a when the embankment fill

242 is higher than $2 \mathrm{~m}$ and other conditions being equal. For example, the use of large-strain mode 243 for Case 2 unit cell resulted in the maximum vertical stress at the foundation surface of about 14 $244 \mathrm{kPa}$ at $1-\mathrm{m}$ high embankment fill (same as $14 \mathrm{kPa}$ in Figure 3a), and about $32 \mathrm{kPa}$ at 5-m high 245 embankment fill (compared to $22 \mathrm{kPa}$ in Figure 3a). The maximum difference between the large- and small-strain modes for the maximum vertical stresses at the foundation surface with 
247 Case 2 unit cell was about $4 \mathrm{kPa}$ at 5-m high embankment fill compared to less than $1 \mathrm{kPa}$ with 248 Case 1 unit cell. Figure $6 \mathbf{b}$ shows the maximum settlements at the foundation surface for Case 2 249 unit cell with a spring stiffness value of $k=1 \mathrm{MPa} / \mathrm{m}$ using both large- and small-strain modes. 250 The results show that the use of horizontal springs at right side of the unit cell (Figure 2b) resulted in larger maximum settlements at the foundation surface compared to those in Figure $\mathbf{3 b}$

252 for embankment fills higher than $1 \mathrm{~m}$ and other conditions being equal. The maximum difference 253 between the large- and small-strain modes for the vertical settlement at 5-m high embankment 254 fill was larger for Case 2 unit cell (about $23 \mathrm{~mm}$ ) than for Case 1 unit cell (about $3 \mathrm{~mm}$ ).

The normal stresses on the DM column wall top and foundation surface for Case 2 unit cell with

257 spring stiffness of $k=1 \mathrm{MPa} / \mathrm{m}$ are shown in Figure 7a. When using the large-strain mode, the 258 normal stress for Case 2 unit cell was about $309 \mathrm{kPa}$ at $x=0$ (compared to $332 \mathrm{kPa}$ for Case 1 259 unit cell in Figure 4a), about $373 \mathrm{kPa}$ at $x=0.35 \mathrm{~m}$ (compared to $388 \mathrm{kPa}$ in Figure 4a), less 260 than $33 \mathrm{kPa}$ between $x=0.35$ and $2.45 \mathrm{~m}$ (compared to less than $24 \mathrm{kPa}$ in Figure 4a), about 480 $261 \mathrm{kPa}$ at $x=2.45 \mathrm{~m}$ (compared to $388 \mathrm{kPa}$ in Figure 4a), and about $164 \mathrm{kPa}$ at $x=2.8 \mathrm{~m}$ 262 (compared to $332 \mathrm{kPa}$ for Case 1 unit cell in Figure 4a). Figure 7b indicates that lateral 263 spreading of embankment fill and foundation soil can also influence the vertical stress 264 distribution within the embankment fill. This can be seen by comparing Figure $7 \mathbf{b}$ for Case 2 265 unit cell with Figure 4b for Case 1 unit cell.

267 Figure 8 shows the reinforcement tensile loads for Case 2 unit cell with spring stiffness $k=1$ $268 \mathrm{MPa} / \mathrm{m}$. The results show that lateral spreading of the embankment fill and foundation soil can 269 have significant influence on the reinforcement loads. For example, the use of Case 2 unit cell 270 with spring stiffness $k=1 \mathrm{MPa} / \mathrm{m}$ and large-stain mode resulted in the reinforcement load of 271 about $31 \mathrm{kN} / \mathrm{m}$ at $x=0$ (compared to $8 \mathrm{kN} / \mathrm{m}$ for Case 1 unit cell in Figure 5), about $40 \mathrm{kN} / \mathrm{m}$ at $272 x=0.35 \mathrm{~m}$ (compared to $11 \mathrm{kN} / \mathrm{m}$ in Figure 5), about $15 \mathrm{kN} / \mathrm{m}$ at $x=1.4 \mathrm{~m}$ (compared to 1.6 $273 \mathrm{kN} / \mathrm{m}$ in Figure 5), about $38 \mathrm{kN} / \mathrm{m}$ at $x=2.45 \mathrm{~m}$ (compared to $11 \mathrm{kN} / \mathrm{m}$ in Figure 5), and about $27417 \mathrm{kN} / \mathrm{m}$ at $x=2.8 \mathrm{~m}$ (compared to $8 \mathrm{kN} / \mathrm{m}$ in Figure 5). Using the small-strain mode, the 275 maximum reinforcement load was $31 \mathrm{kN} / \mathrm{m}$ at $x=2.45 \mathrm{~m}$ in Figure 8 compared to $3 \mathrm{kN} / \mathrm{m}$ at $x=$ 2760 and $2.8 \mathrm{~m}$ for Case 1 in Figure 5. It is the lateral spreading of embankment fill and foundation 277 soil that occurs using the Case 2 unit cell that results in greater axial extension of the 
278 reinforcement and thus larger reinforcement loads for the Case 2 unit cell compared to the Case 1

279 unit cell.

4.3 Influence of Spring Stiffness on Reinforcement Loads for Case 2

283 The choice of magnitude of the spring stiffness can affect the lateral displacements generated 284 within the embankment fill and foundation soil. These displacements will also depend on where 285 the Case 2 unit cell is taken along the full-width of the GRCS embankment (e.g., near the center 286 line or toe of the embankment due to different fill depths). The influence of different spring 287 stiffness values on the reinforcement loads with large-strain mode and 5-m high embankment fill 288 is shown in Figure 9 (both the embankment fill and the soft foundation soil were assumed to 289 have the same spring stiffness in this example). The numerical results show that the 290 reinforcement loads decreased with increasing soil spring stiffness because of less lateral 291 spreading of embankment fill and foundation soil associated with higher spring stiffness. For 292 example, the maximum reinforcement load for Case 2 unit cell was about $40 \mathrm{kN} / \mathrm{m}$ when using 293 spring stiffness $k=1 \mathrm{MPa} / \mathrm{m}$, but decreased to about 19,11 and $11 \mathrm{kN} / \mathrm{m}$ when increased to $k=$ $29410 \mathrm{MPa}, 100 \mathrm{MPa}$ and infinite stiffness, respectively.

The spring stiffness of the soft foundation soil can be different from that of the embankment fill.

297 The influence of different foundation soil spring stiffness values on reinforcement loads below a 298 5-m high embankment fill using large-strain mode is shown in Figure 10. The results show that 299 increasing the spring stiffness value of the foundation soil reduced the reinforcement loads 300 because less lateral spreading of the foundation soil resulted in less differential displacement 301 between the reinforcement and platform fill. For example, the maximum reinforcement load was 302 about $44 \mathrm{kN} / \mathrm{m}$ for the foundation spring stiffness of $k_{\mathrm{f}}=0.1 \mathrm{MPa} / \mathrm{m}$ and decreased to about 40 303 and $35 \mathrm{kN} / \mathrm{m}$ for $k_{\mathrm{f}}=1$ and $10 \mathrm{MPa} / \mathrm{m}$, respectively.

\subsection{Unit Cell for Case 3}

307 In this section, the lateral spreading of the embankment fill and foundation soil on both sides of 308 the cell is considered using springs on both sides of the unit cell (Case 3 unit cell in Figure 2c). 
309 Figure 11 shows the maximum vertical stresses and settlements at the foundation surface for 310 Case 3 unit cell with spring stiffness values of $k_{1}=k_{\mathrm{r}}=1 \mathrm{MPa} / \mathrm{m}$ using both small- and large311 strain modes. The results show that the use of lateral springs on both sides of the unit cell 312 resulted in maximum vertical stresses of 42 and $36 \mathrm{kPa}$ (compared to 36 and $32 \mathrm{kPa}$ for Case 2 313 unit cell) and maximum settlements of 192 and $151 \mathrm{~mm}$ (compared to 149 and $126 \mathrm{~mm}$ for Case

3142 unit cell) for the 5-m high embankment fill simulations using the small- and large-strain 315 modes, respectively.

317 Figure 12 shows the interface normal stresses at the foundation surface and vertical stresses at 318 the center of the unit cell for the 5-m high embankment fill and Case 3 unit cell with spring 319 stiffness values of $k_{1}=k_{\mathrm{r}}=1 \mathrm{MPa} / \mathrm{m}$. The maximum interface normal stress was about 462 and $320538 \mathrm{kPa}$ at the intersection between the DM column wall and soft foundation soil for simulations 321 in small- and large-stain mode, respectively (Figure 12a). These values are greater than those for 322 Case 2 unit cell (i.e., 421 and $480 \mathrm{kPa}$ in Figure 7a for the small- and large-strain modes, 323 respectively). The differences in vertical stresses at the center of the unit cell between Case 3 and 324 Case 2 unit cells can also be observed by comparing results from Figure 12b with those from 325 Figure $7 \mathbf{b}$.

327 Figure 13 shows the reinforcement loads for Case 3 unit cell at 5-m high embankment fill using 328 both small- and large-strain modes and spring stiffness values of $k_{1}=k_{\mathrm{r}}=1 \mathrm{MPa} / \mathrm{m}$. The maximum reinforcement loads for Case 3 unit cell were about 34 and $44 \mathrm{kN} / \mathrm{m}$ using small- and large-strain modes, respectively. The maximum difference in reinforcement load using large- and

\subsection{Influence of Spring Stiffness on Reinforcement Loads for Case 3}

335 The influence of different spring stiffness values at left side and right of the unit cell (Case 3) on the reinforcement loads is shown in Figure 14 using large-strain mode. In this example the 337 embankment fill is $5 \mathrm{~m}$ high and the spring stiffness at the right side of the unit cell is fixed at $k_{\mathrm{r}}$ $338=1 \mathrm{MPa} / \mathrm{m}$. Increasing the spring stiffness at left side of the unit cell increased the reinforcement 339 load at $x=0$ but had negligible effect on the reinforcement load at $x=2.8 \mathrm{~m}$. Using spring 
340 stiffness greater than $k_{1}=10 \mathrm{MPa} / \mathrm{m}$ at left side of the unit cell had minor influence on the

341 reinforcement loads between $x=0.35$ and $2.8 \mathrm{~m}$.

\section{Conclusions}

An effective technique to improve the performance of embankments over soft foundations is to use geosynthetic-reinforced and column-supported (GRCS) embankments. Both full-width model and unit cell approaches have been used by researchers to study the behaviour of these structures. However, the typical unit cell with fixed horizontal displacements at side boundaries is unable to capture the lateral spreading of the embankment fill and foundation soil. Khabbazian et al. (2015) showed that this can lead to large differences in numerical outcomes between a full-width model and the simulation of the same structures using the typical unit cell

352 approach. This paper presents a modified unit cell approach to simulate the lateral spreading of 353 the embankment fill and foundation soil using horizontal linear elastic springs at the vertical 354 boundaries of the unit cell. Program FLAC is used to examine the influence of large- and small355 strain mode on conventional and modified unit cell behaviour. Based on the numerical results 356 using the three different unit cells examined in this paper, the following conclusions can be 357 summarized:

- For a typical unit cell with fixed lateral horizontal displacements at the side boundaries (Case 1 unit cell in Figure 2a), the use of large- and small-strain mode has minor influence on the maximum vertical stresses and settlements, and interface normal stresses at the foundation surface. However, when the numerical model was run in small-strain mode, the calculated reinforcement loads were much lower compared to large-strain mode.

- For the modified unit cells with lateral springs (Case 2 unit cell in Figure 2b and Case 3 unit cell in Figure 2c), the lateral spreading of the embankment fill and foundation soil increased the maximum vertical stresses and settlements at the foundation surface, and the reinforcement loads when compared to numerical results using fixed side boundaries (Case 1 unit cell) and other conditions being equal. 
- The magnitude of calculated reinforcement loads for Case 2 and 3 unit cell examples depended on the choice of lateral spring stiffness value and whether or not the same stiffness value was assigned to the embankment fill and foundation soil.

373 This paper has demonstrated that lateral spreading of the embankment fill and foundation soil

374 can be modelled using a modified unit cell with a series of lateral springs supporting one or both

375 side boundaries. However, numerical outcomes depended on the choice of small-strain or large-

376 strain mode when using program FLAC. The computed reinforcement loads were particularly

377 sensitive to this choice.

379 The influence of equivalent large-strain mode in FEM programs (i.e., mesh updating option) was 380 not investigated in this study. However, similar sensitivity to choice of fixed or updated mesh 381 generation on reinforcement loads using these codes is expected.

\section{Acknowledgement}

The work reported in this paper was supported by grants from the Natural Sciences and Engineering Research Council of Canada (NSERC).

\section{References}

Bergado, D.T., Ruenkrairergsa, T., Taesiri, Y., and Balasubramaniam, A.S. (1999). Deep soil mixing used to reduce embankment settlement. Ground Improvement. 3, 145-162.

Borges, J.L., and Marques, D.O. (2011). Geosynthetic-reinforced and jet grout column-supported embankments on soft soils: numerical analysis and parametric study. Computers and Geotechnics. 38: 883-896.

Briançon, L., and Simon, B. (2012). Performance of pile-supported embankment over soft soil: full-scale experiment. ASCE Journal of Geotechnical and Geoenvironmental Engineering, 138 (4): 551-561. 
G\&G v5

Bruce, M.E.C., Berg, R.R., Collin, J.G., Filz, G.M., Terashi, M., and Yang, D.S. (2013). Federal Highway Administration Design Manual: Deep Mixing for Embankment and Foundation Support. U.S. Department of Transportation, USA, 248 p.

BS8006 (2010). Code of Practice for Strengthened/Reinforced Soil and Other Fills, British Standards Institution (BSI). Milton Keynes, UK.

Canadian Geotechnical Society. (2006). Canadian Foundation Engineering Manual. 4th Ed. BiTech Publishers Ltd., Richmond, B.C.

Chai, J.C., Shrestha, S., Hino, T., Ding, W.Q., Kamo, Y., and Carter, J. (2015). 2D and 3D analyses of an embankment on clay improved by soil-cement columns. Computers and Geotechnics. 68: 28-37.

EBGEO (2011). Recommendations for Design and Analysis of Earth Structures using Geosynthetic Reinforcements - EBGEO. German Geotechnical Society, ISBN: 978-3-43302983-1, and Digital Version in English, ISBN: 978-3-433-60093-1.

Forsman, J., Honkala, A., and Smura, M. (1999). Hertsby case: a column stabilized and geotextile reinforced road embankment on soft subsoil. Dry Mix Method for Deep Soil Stabilization. Balkema, Rotterdam, The Netherlands, pp. 263-268.

Han, J., and Gabr, M.A. (2002). Numerical analysis of geosynthetic reinforced and pilesupported earth platforms over soft soil. ASCE Journal of Geotechnical and Geoenvironmental Engineering. 128(1): 44-53.

Han, J., Oztoprak, S., Parsons, R.L., and Huang, J. (2007). Numerical analysis of foundation columns to support widening of embankments. Computers and Geotechnics. 34(6): 435448.

Hewlett, W.J., and Randolph, M.F. (1988). Analysis of piled embankments. Ground Engineering. 21(3):12-18.

Hosseinpour, I., Almeida, M.S.S., and Riccio, M. (2015). Full-scale load test and finite-element analysis of soft ground improved by geotextile-encased granular columns. Geosynthetics International. [http://dx.doi.org/10.1680/gein.15.00023]

Huang, J., and Han, J. (2009). 3D coupled mechanical and hydraulic modeling of a geosyntheticreinforced deep mixed column-supported embankment. Geotextiles and Geomembranes. 27: $272-280$. 
Huang, J., and Han, J. (2010). Two-dimensional parametric study of geosynthetic-reinforced column-supported embankments by coupled hydraulic and mechanical modeling. Computers and Geotechnics. 37: 638-648.

Huang, J., Han, J., and Oztoprak, S. (2009). Coupled mechanical and hydraulic modeling of geosynthetic-reinforced column-supported embankments. ASCE Journal of Geotechnical and Geoenvironmental Engineering. 135: 1011-1021.

Itasca. (2011). FLAC: Fast Lagrangian Analysis of Continua. Version 7.0 [computer program]. Itasca Consulting Group, Inc., Minneapolis, MN.

Kempfert, H.G., Göbel, C., Alexiew, D., and Heitz, C. (2004). German recommendations for the reinforced embankments on pile-similar elements. In Proceedings of the 3rd European Conference on Geosynthetics, Munich, Germany, pp. 279-284.

Khabbazian, M., Kaliakin V.N., and Meehan, C.L. (2015). Column supported embankments with geosynthetic encased columns: validity of the unit cell concept. Geotechnical and Geological Engineering. 33: 425-442.

Lai, Y.P., Bergado, D.T., Lorenzo, G.A., and Duangchan, T. (2006). Full-scale reinforced embankment on deep jet mixing improved ground. Ground Improvement. 10(4):153-164.

Liu, H.L., Ng, C.W.W., and Fei, K., (2007). Performance of geogrid-reinforced and pilesupported highway embankment over soft clay: case study. ASCE Journal of Geotechnical and Geoenvironmental Engineering. 133: 1483-1493.

Liu, K.W., and Rowe, R.K. (2015). Numerical study of the effects of geosynthetic reinforcement viscosity on behaviour of embankments supported by deep-mixing method (DMM) columns. Geotextiles and Geomembranes. http://dx.doi.org/10.1016/j.geotexmem.2015.04.020.

Nunez, M.A., Briancon, L., and Dias, D. (2013). Analyses of a pile-supported embankment over soft clay: Full-scale experiment, analytical and numerical approaches. Engineering Geology. 153: 53-67.

Rowe, R.K., and Liu, K.W., (2015). 3D finite element modeling of a full-scale geosyntheticreinforced, pile-supported embankment. Canadian Geotechnical Journal. http://dx.doi.org/10.1139/cgj-2014-0506.

Smith, M., and Filz, G. (2007). Axisymmetric numerical modeling of a unit cell in geosyntheticreinforced, column-supported embankments. Geosynthetics International. 14(1): 13-22. 
G\&G v5

Van Eekelen, S.J.M., Bezuijen, A., and van Tol, A.F. (2011). Analysis and modification of the British Standard BS8006 for the design of piled embankments. Geotextiles and Geomembranes. 29: 345-359.

462 Yapage, N.N.S., and Liyanapathirana, D.S. (2014). A parametric study of geosynthetic463 reinforced column-supported embankments. Geosynthetics International. 21(3): 213-232.

464 Yoo, C. (2010). Performance of geosynthetic-encased stone columns in embankment 465 construction: numerical investigation. ASCE Journal of Geotechnical and 466 Geoenvironmental Engineering. 136(8): 1148-1160.

467 Zhang, J., Zheng, J.J., Chen, B.G., and Yin, J.H. (2013). Coupled mechanical and hydraulic 468 modeling of a geosynthetic-reinforced and pile-supported embankment. Computers and 469 Geotechnics. 52: 28-37.

470 Yu, Y., Damians, I.P., and Bathurst, R.J. 2015. Influence of choice of FLAC and PLAXIS 471 interface models on reinforced soil-structure interactions. Computers and Geotechnics, 65: $472 \quad 164-174$. 
473 Table 1. Material property values in FLAC.

474

\begin{tabular}{ll}
\hline Properties & Value \\
\hline Embankment and working platform fill & \\
Unit weight, $\gamma_{\mathrm{ef}}\left(\mathrm{kN} / \mathrm{m}^{3}\right)$ & 20 \\
Young's modulus, $E_{\mathrm{ef}}(\mathrm{MPa})$ & 40 \\
Poisson's ratio, $v_{\mathrm{ef}}(-)$ & 0.3 \\
Friction angle, $\phi_{\mathrm{ef}}($ degree$)$ & 35 \\
Dilation angle, $\psi_{\mathrm{ef}}($ degree $)$ & 5 \\
Cohesion, $c_{\mathrm{ef}}(\mathrm{kPa})$ & 1 \\
& \\
Soft foundation soil & \\
Unit weight, $\gamma_{\mathrm{fs}}\left(\mathrm{kN} / \mathrm{m}^{3}\right)$ & 16 \\
Young's modulus of soft clay $1, E_{\mathrm{fs}, 1}(\mathrm{MPa})$ & 0.5 \\
Young's modulus of soft clay $2, E_{\mathrm{fs}, 2}(\mathrm{MPa})$ & 1.0 \\
Young's modulus of soft clay $3, E_{\mathrm{fs}, 3}(\mathrm{MPa})$ & 1.5 \\
Young's modulus of soft clay $4, E_{\mathrm{fs}, 4}(\mathrm{MPa})$ & 2.0 \\
Young's modulus of soft clay $5, E_{\mathrm{fs}, 5}(\mathrm{MPa})$ & 2.5 \\
Poisson's ratio, $\nu_{\mathrm{fs}}(-)$ & 0.25 \\
Friction angle, $\phi_{\mathrm{fs}}(\mathrm{degree})$ & 15 \\
Dilation angle, $\psi_{\mathrm{fs}}($ degree $)$ & 0 \\
Cohesion, $c_{\mathrm{fs}}(\mathrm{kPa})$ & 5 \\
& \\
DM column & 20 \\
Unit weight, $\gamma_{\mathrm{c}}\left(\mathrm{kN} / \mathrm{m}^{3}\right)$ & 150 \\
Young's modulus, $E_{\mathrm{c}}(\mathrm{MPa})$ & 0.3 \\
Poisson's ratio, $v_{\mathrm{c}}(-)$ & \\
\hline
\end{tabular}


477 Table 2. Interfaces and corresponding parameter values in FLAC.

478

\begin{tabular}{ll}
\hline Interface and parameters & Value \\
\hline $\begin{array}{l}\text { Soft clay-DM column and } \\
\text { soft clay-platform fill }\end{array}$ & \\
Friction angle, $\phi_{\mathrm{i}, \mathrm{fs}}($ degree $)$ & 10 \\
Dilation angle, $\psi_{\mathrm{i}, \mathrm{fs}}($ degree $)$ & 0 \\
Adhesion, $c_{\mathrm{i}, \mathrm{fs}}(\mathrm{kPa})$ & 3.3 \\
Normal stiffness, $k_{\mathrm{n}, \mathrm{fs}}(\mathrm{MPa} / \mathrm{m})$ & 10 \\
Shear stiffness, $k_{\mathrm{s}, \mathrm{fs}}(\mathrm{MPa} / \mathrm{m})$ & 1
\end{tabular}

\section{Platform fill-DM column}

Friction angle, $\phi_{\text {i,pf }}$ (degree) 25

Dilation angle, $\psi_{\mathrm{i}, \mathrm{pf}}$ (degree) $\quad 0$

Cohesion, $c_{\mathrm{i}, \mathrm{pf}}(\mathrm{kPa}) \quad 0.67$

Normal stiffness, $k_{\mathrm{n}, \mathrm{pf}}(\mathrm{MPa} / \mathrm{m}) \quad 100$

Shear stiffness, $k_{\mathrm{s}, \mathrm{pf}}(\mathrm{MPa} / \mathrm{m}) \quad 10$

Table 3. Parameter values of cable elements in FLAC.

\begin{tabular}{ll}
\hline Cable element parameters $^{\text {a }}$ & Value \\
\hline Young's modulus, $E_{\mathrm{g}}(\mathrm{MPa})$ & 1000 \\
Cross-sectional area, $A_{\mathrm{g}}\left(\mathrm{m}^{2}\right)$ & $2 \times 10^{-3}$ \\
Exposed perimeter, $P_{\mathrm{g}}(\mathrm{m})$ & 2 \\
Grout stiffness, $K_{\mathrm{s}, \mathrm{g}}(\mathrm{MN} / \mathrm{m} / \mathrm{m})$ & 20 \\
Grout cohesion, $C_{\mathrm{g}}(\mathrm{kN} / \mathrm{m})$ & 1.33 \\
Grout frictional resistance, $\phi_{\mathrm{g}}($ degree $)$ & 25 \\
\hline
\end{tabular}




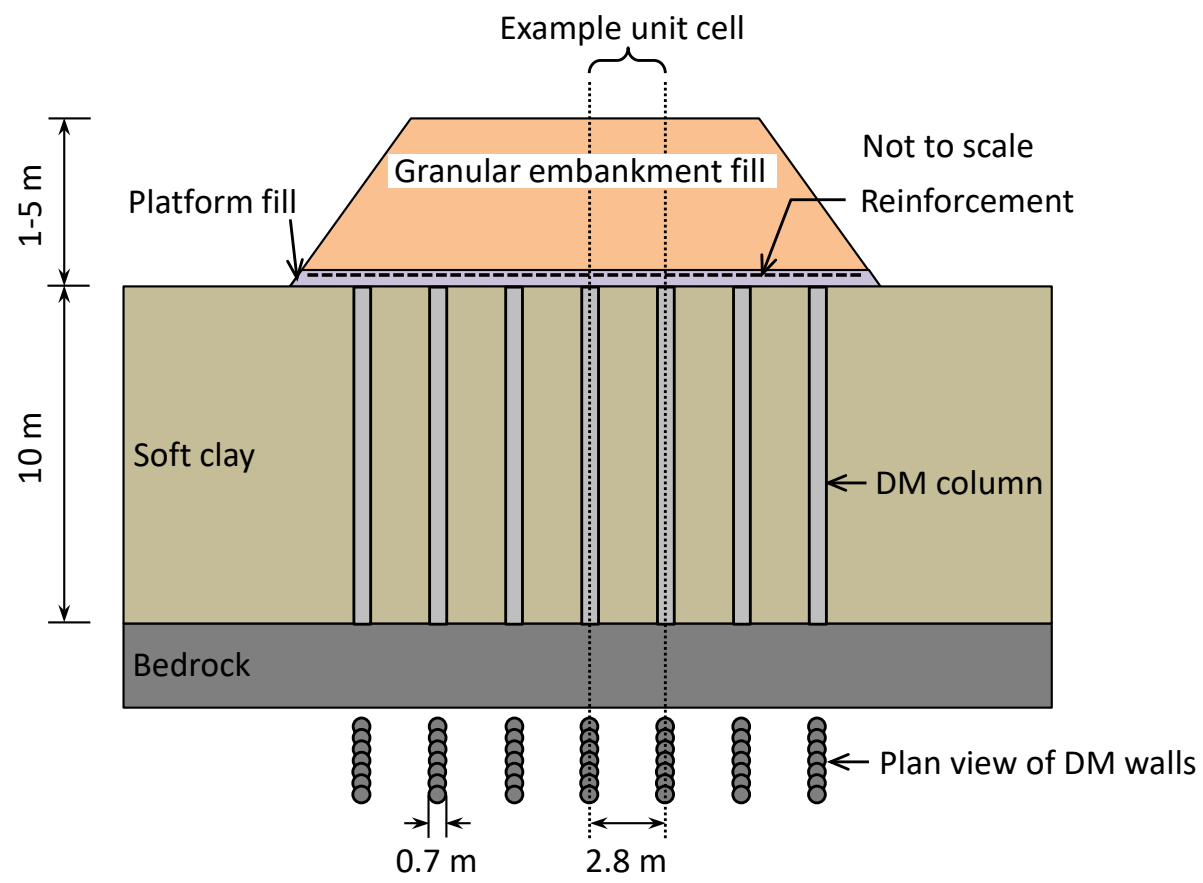

487 Figure 1. Schematic showing a full-width model of the GRCS embankment (with DM column 488 walls).

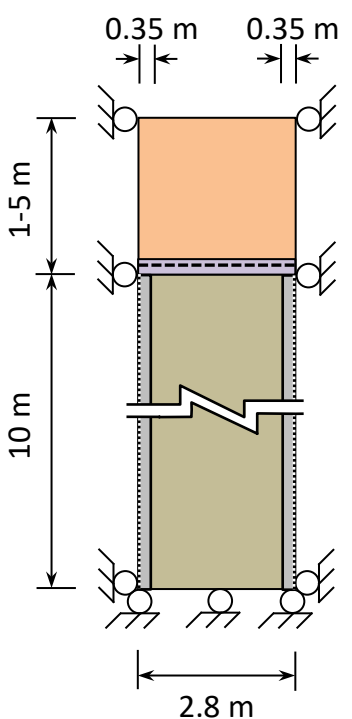

(a)

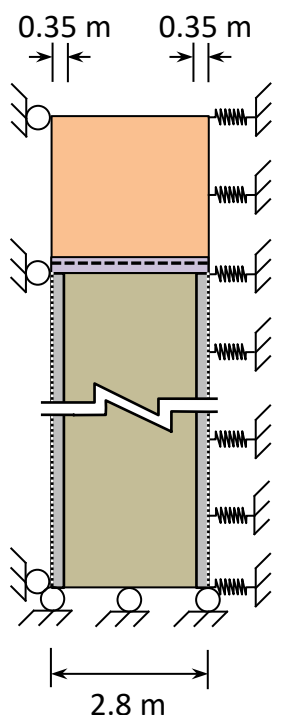

(b)

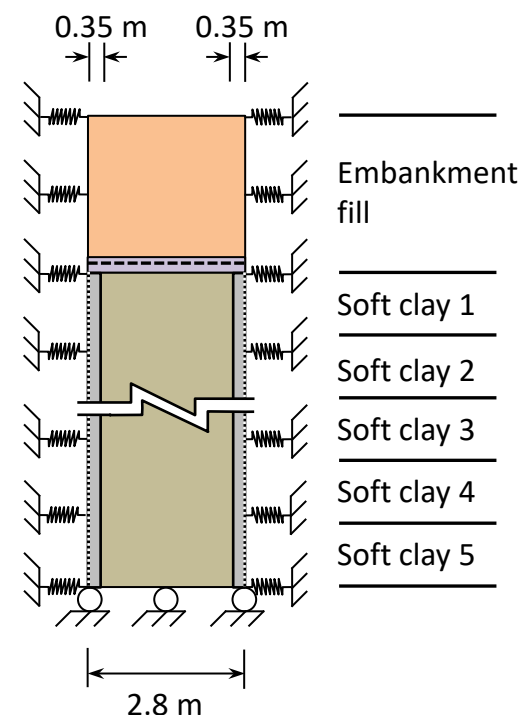

(c)

490 Figure 2. Unit cell (with half of DM column wall on each side of the cell) with: (a) fixed $x$ 491 displacement boundary condition on both left and right sides of the cell (Case 1), (b) fixed $x$ 492 displacement boundary condition on left side and springs on right side of the cell (Case 2), and 493 (c) springs on both left and right sides of the cell (Case 3). 


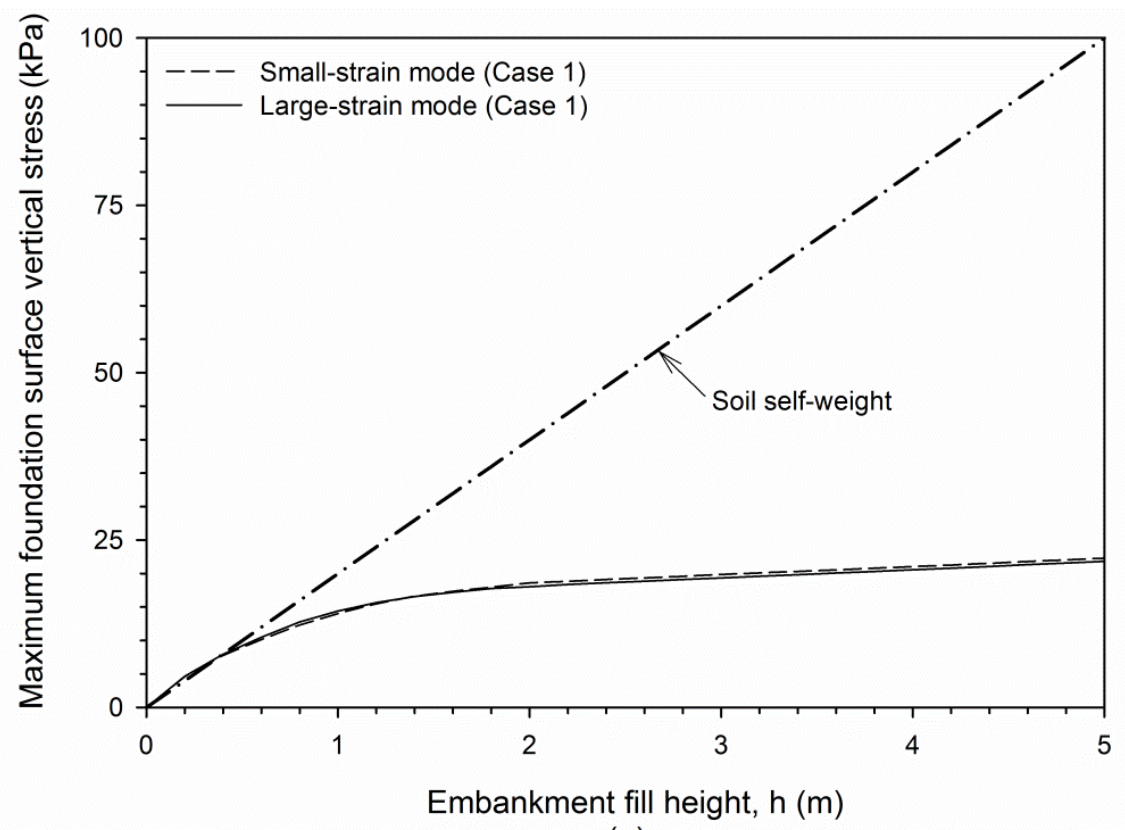

(a)

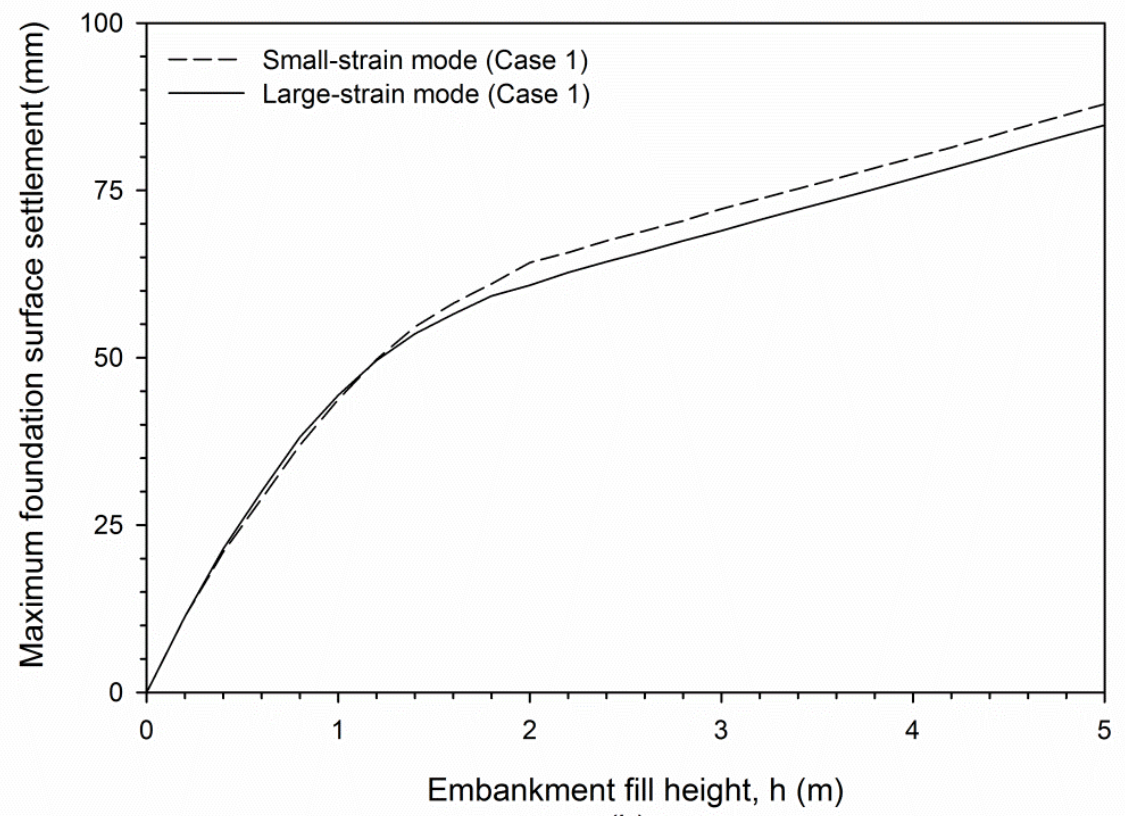

(b)

495 Figure 3. Influence of large- and small-strain mode for Case 1 unit cell on (a) the maximum 496 vertical stresses at the foundation surface and (b) the maximum settlements at the foundation 497 surface. 


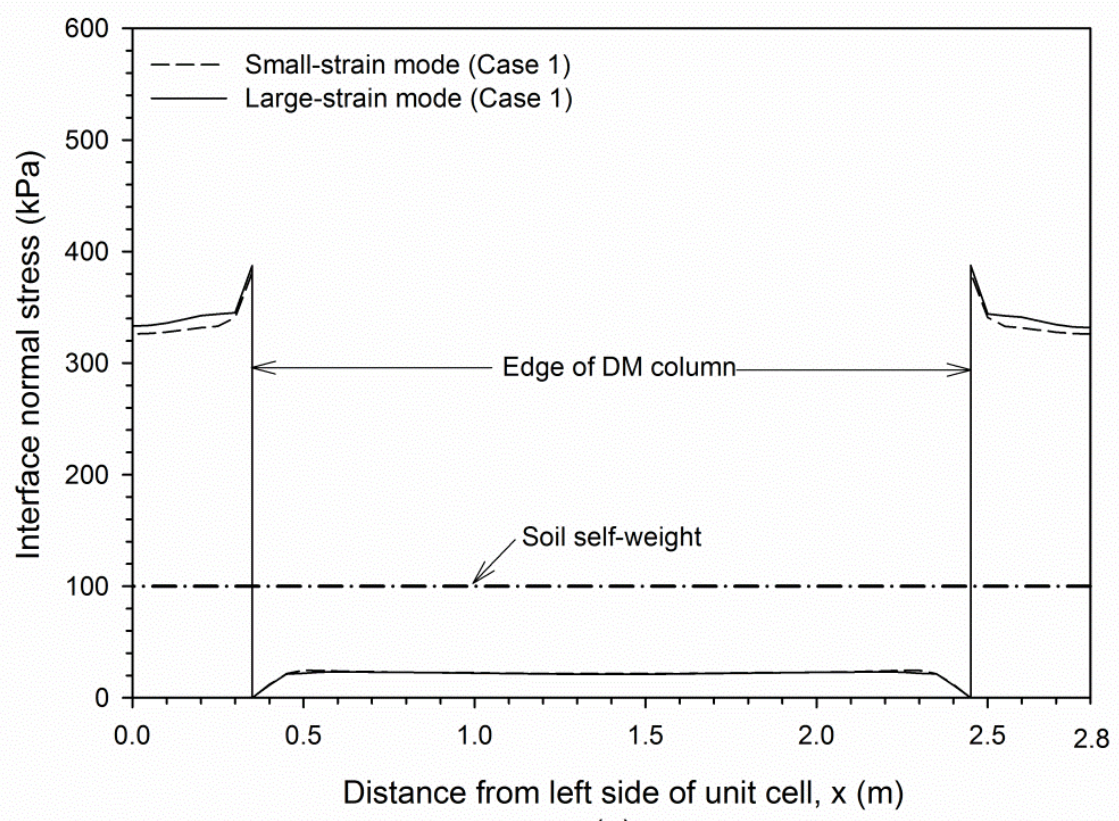

(a)

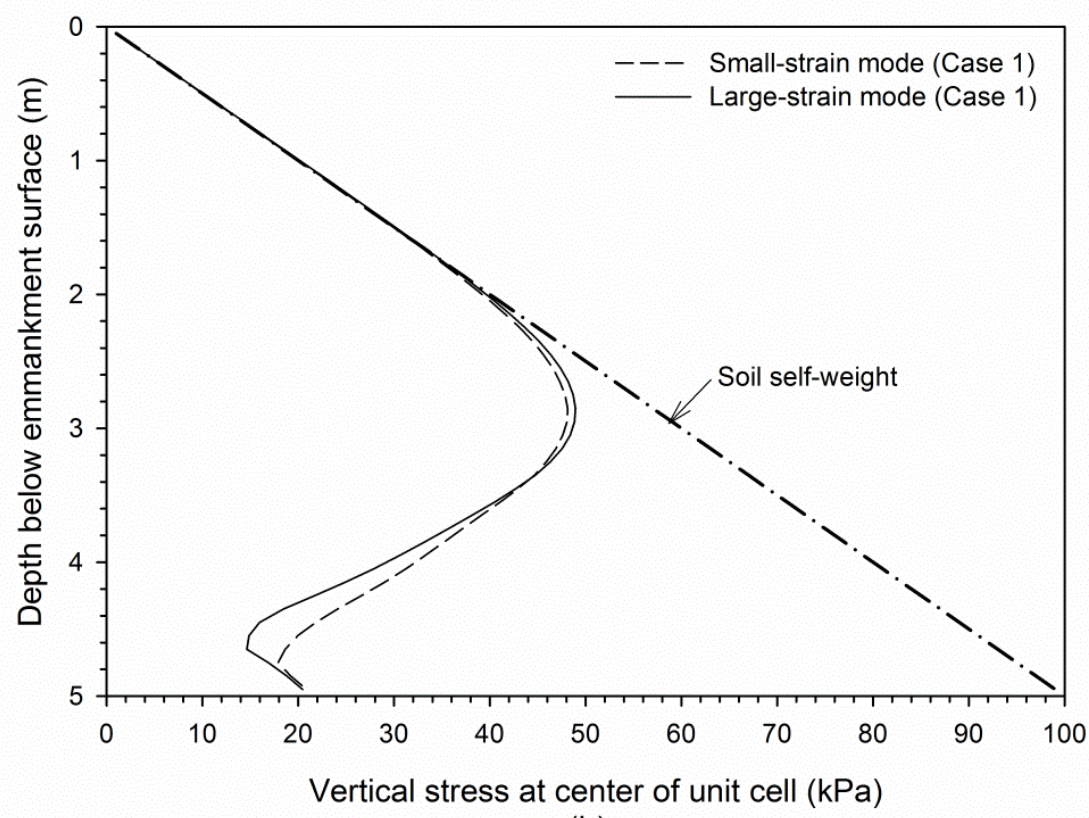

(b)

502 Figure 4. Influence of large- and small-strain mode for Case 1 unit cell with 5-m high 503 embankment fill on (a) the interface normal stresses at the foundation surface elevation, and (b) 504 the vertical stress at the center of the unit cell. 


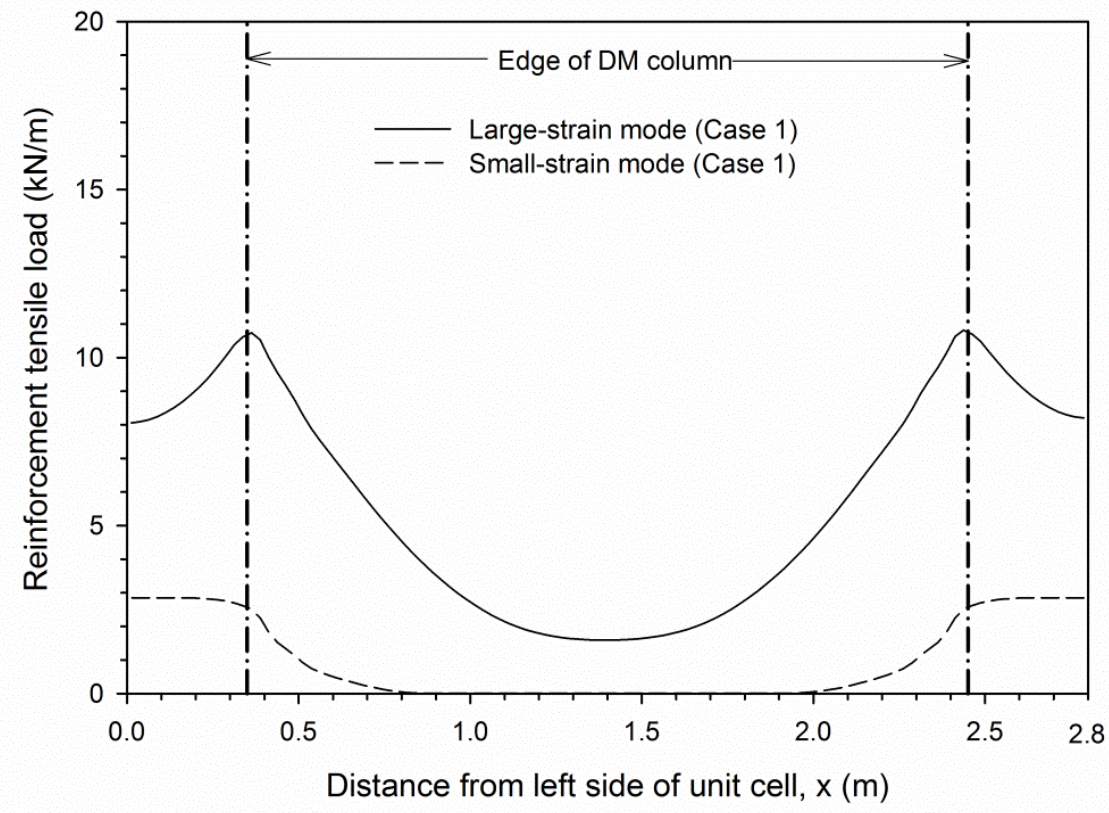

508 Figure 5. Influence of large- and small-strain mode for Case 1 unit cell on the reinforcement 509 tensile loads for 5-m high embankment fill. 


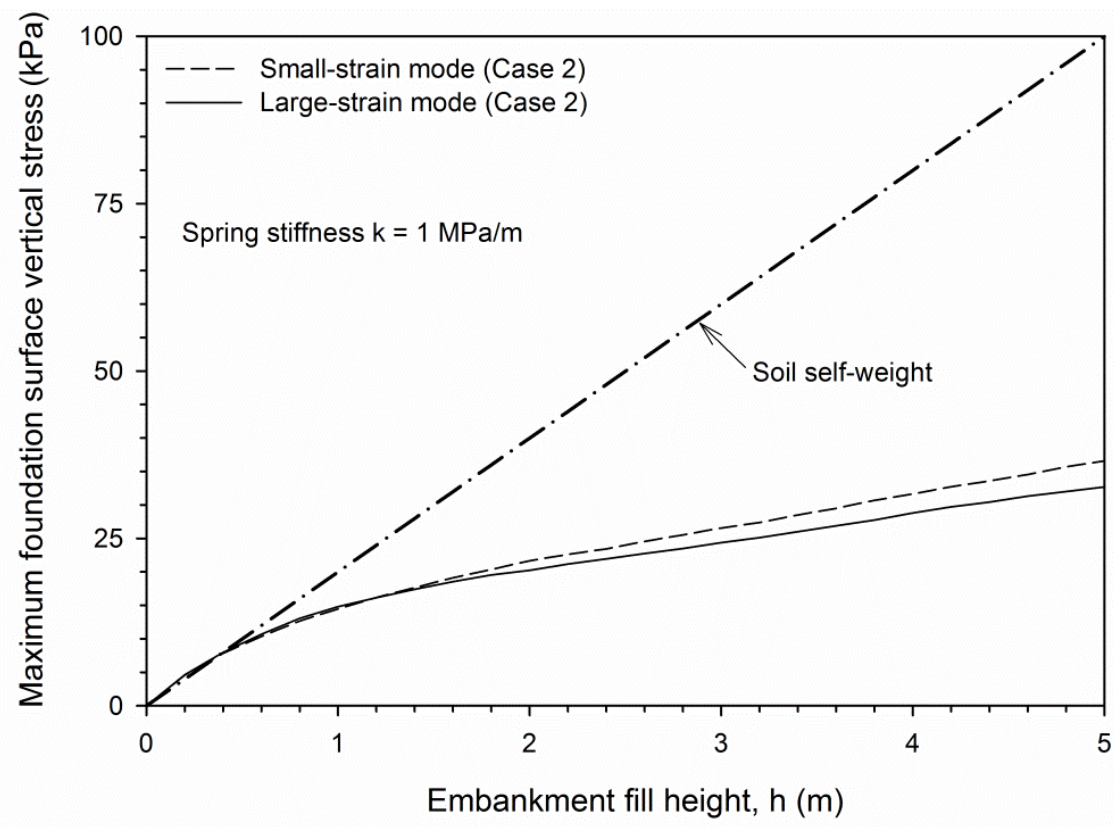

(a)

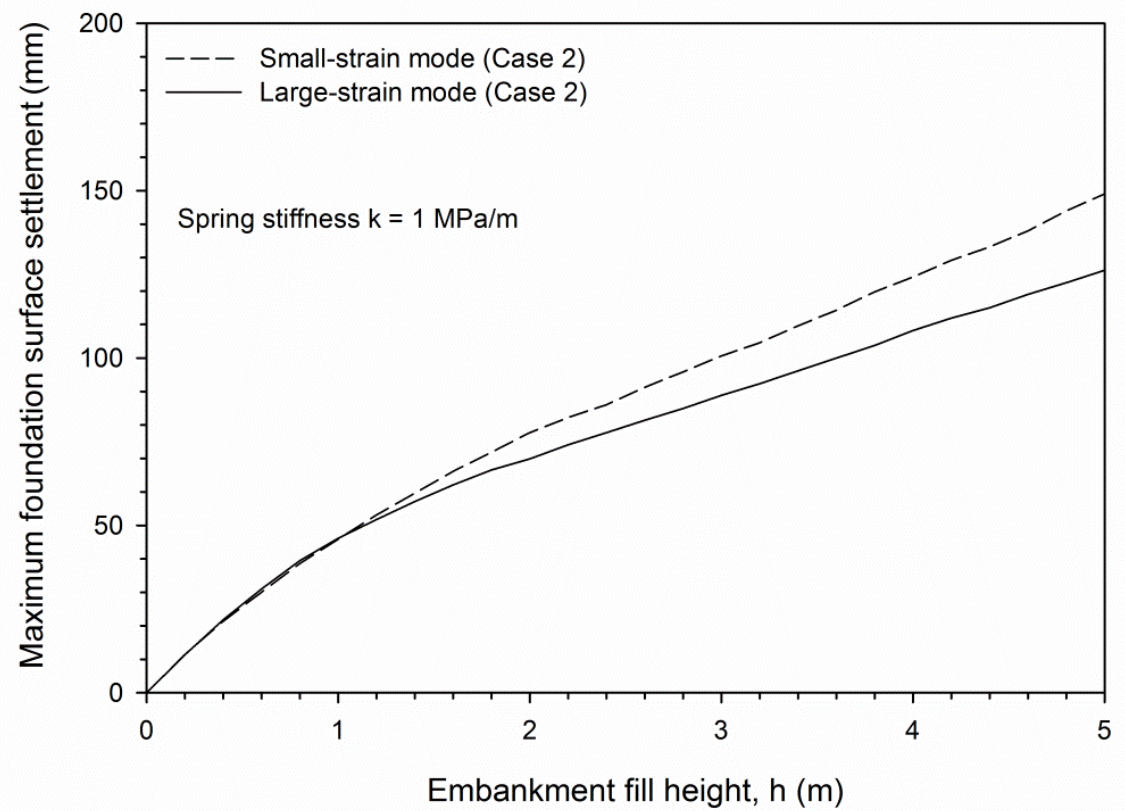

(b)

512 Figure 6. Influence of large- and small-strain mode for Case 2 unit cell with spring stiffness $k=$ $5131 \mathrm{MPa} / \mathrm{m}$ on (a) the maximum vertical stresses at the foundation surface, and (b) the maximum 514 settlements at the foundation surface. 


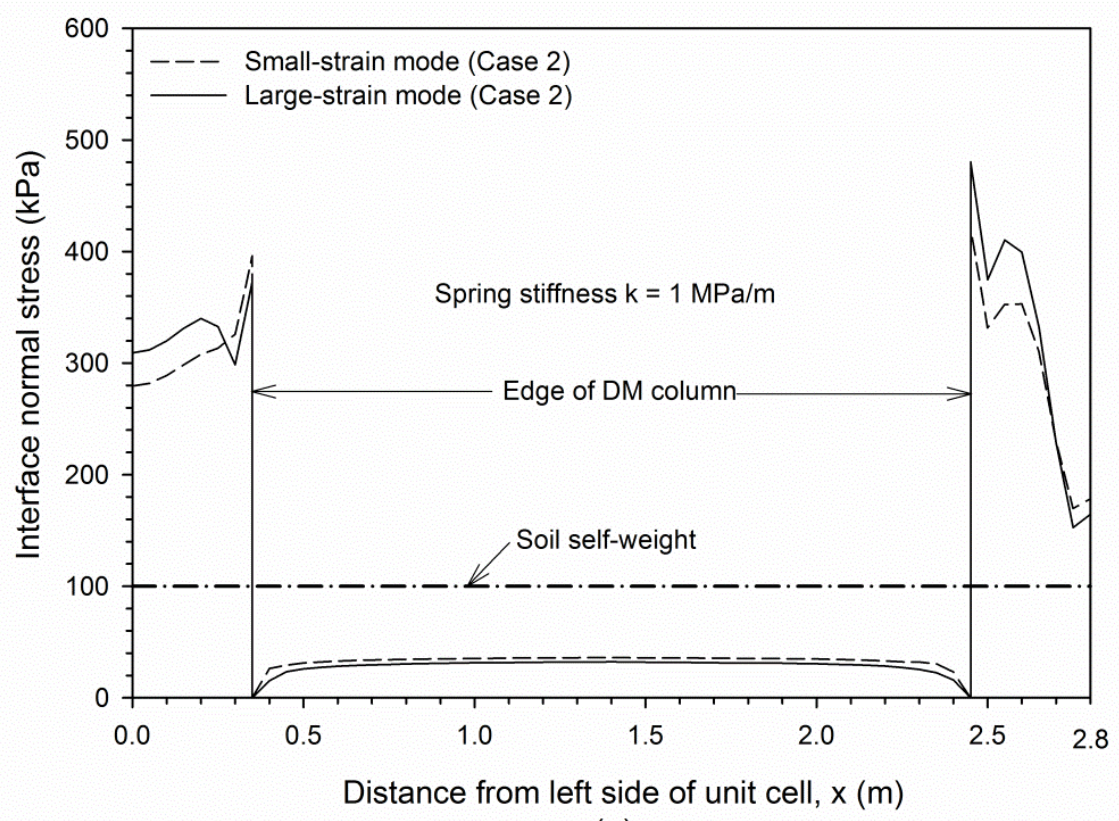

(a)

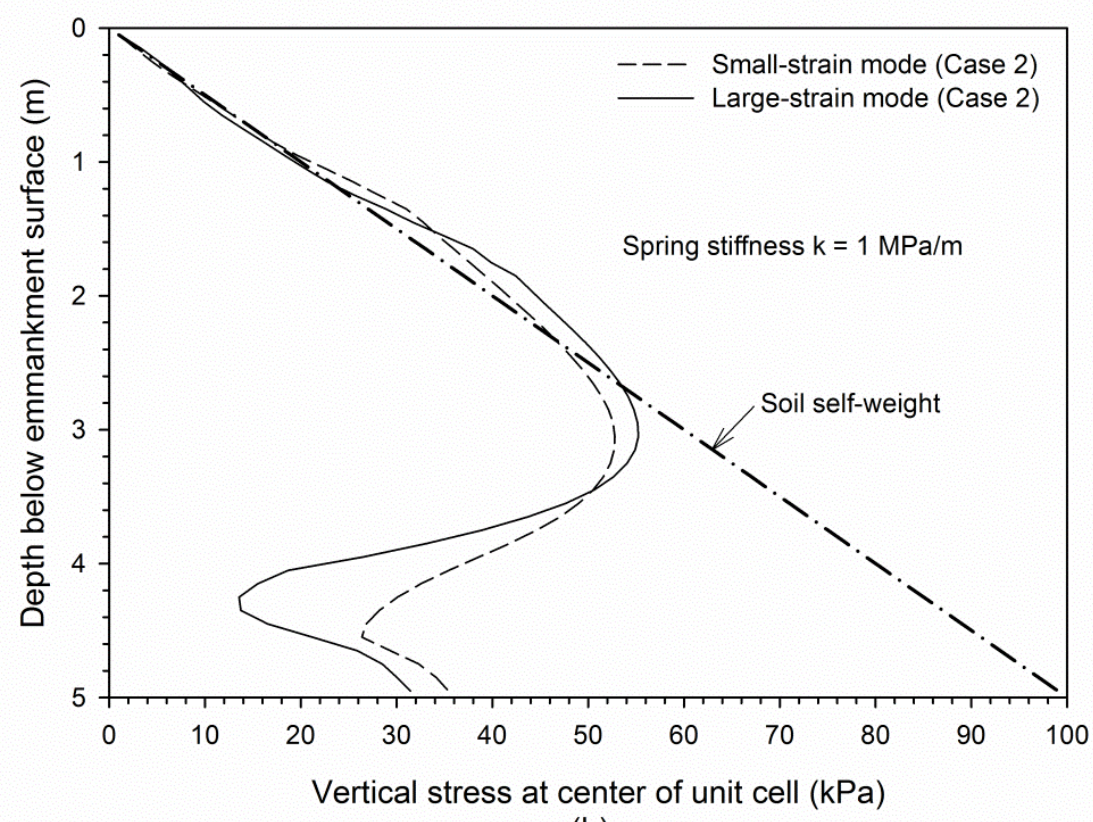

517 Figure 7. Influence of large- and small-strain mode for Case 2 unit cell with spring stiffness $k=$ $5181 \mathrm{MPa} / \mathrm{m}$ on (a) the interface normal stresses at the foundation surface elevation and 5-m high 519 embankment fill, and (b) the vertical stress at the center of unit cell within the embankment fill. 


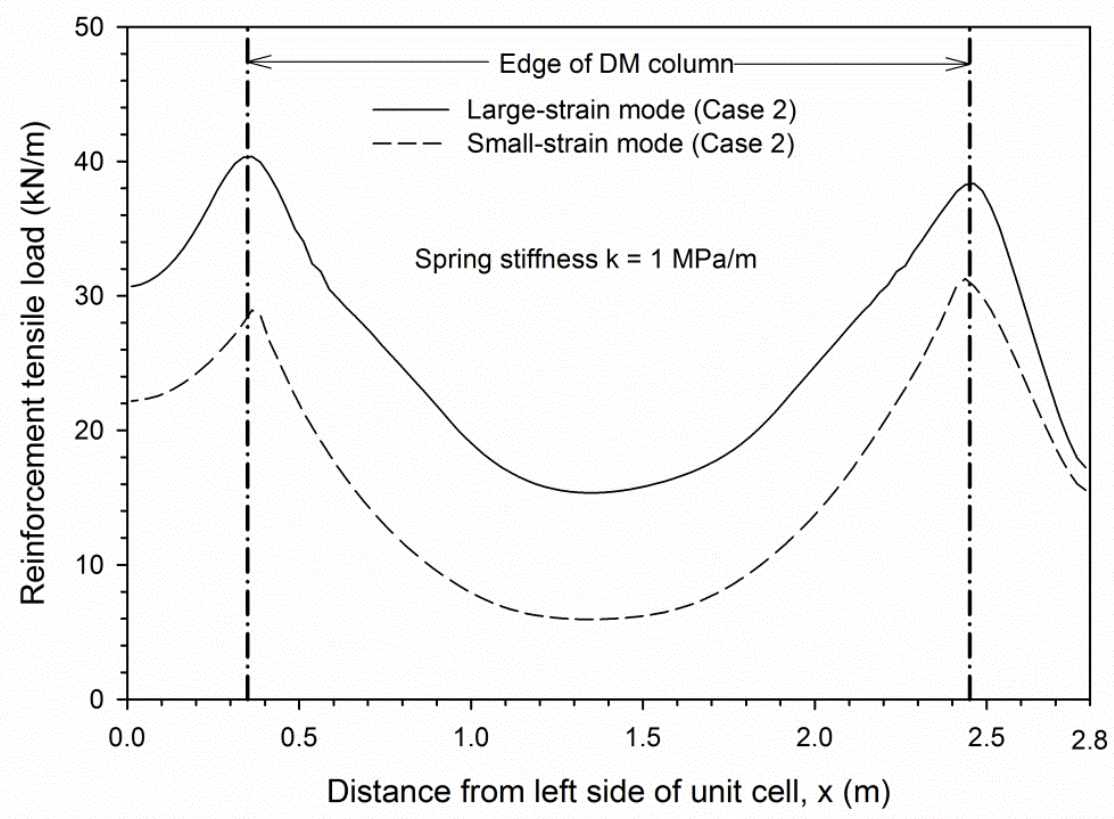

522 Figure 8. Influence of large- and small-strain mode for Case 2 unit cell with spring stiffness $k=$ $5231 \mathrm{MPa} / \mathrm{m}$ on the reinforcement tensile loads for $5-\mathrm{m}$ high embankment fill. 


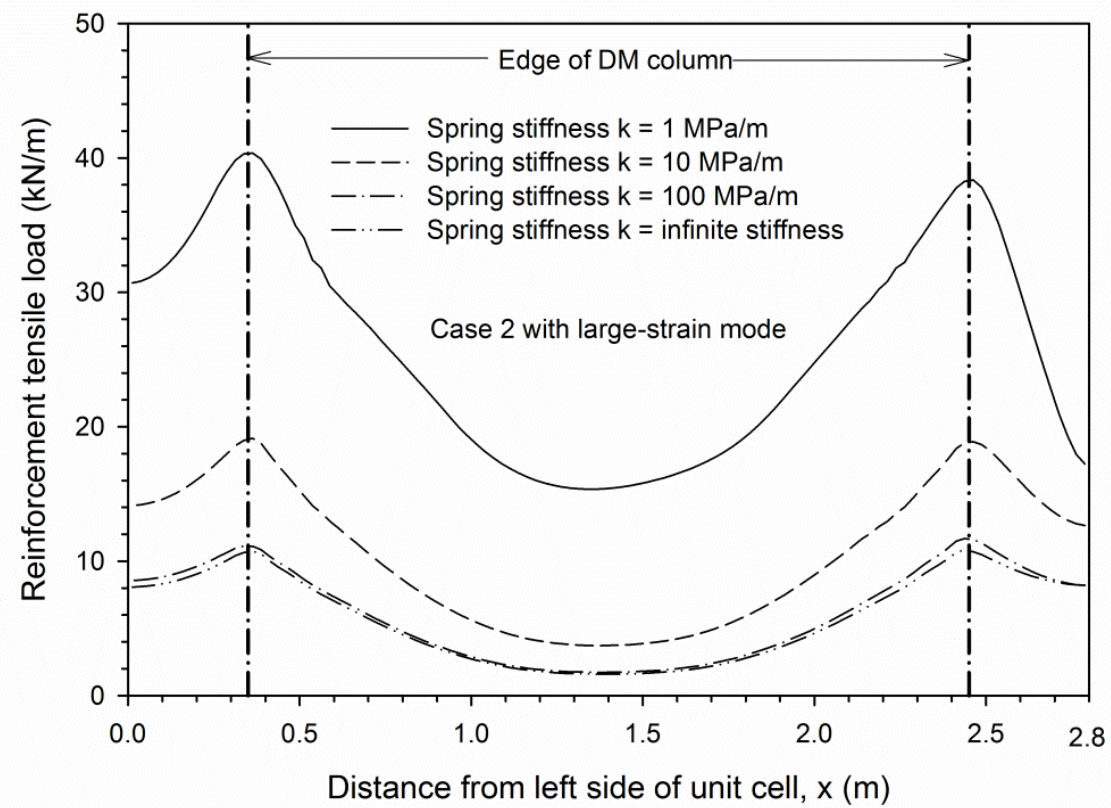

535 Figure 9. Influence of soil spring stiffness values for Case 2 unit cell on the reinforcement tensile loads with large-strain mode at 5-m high embankment fill using the same spring stiffness values for the embankment fill and foundation soil.

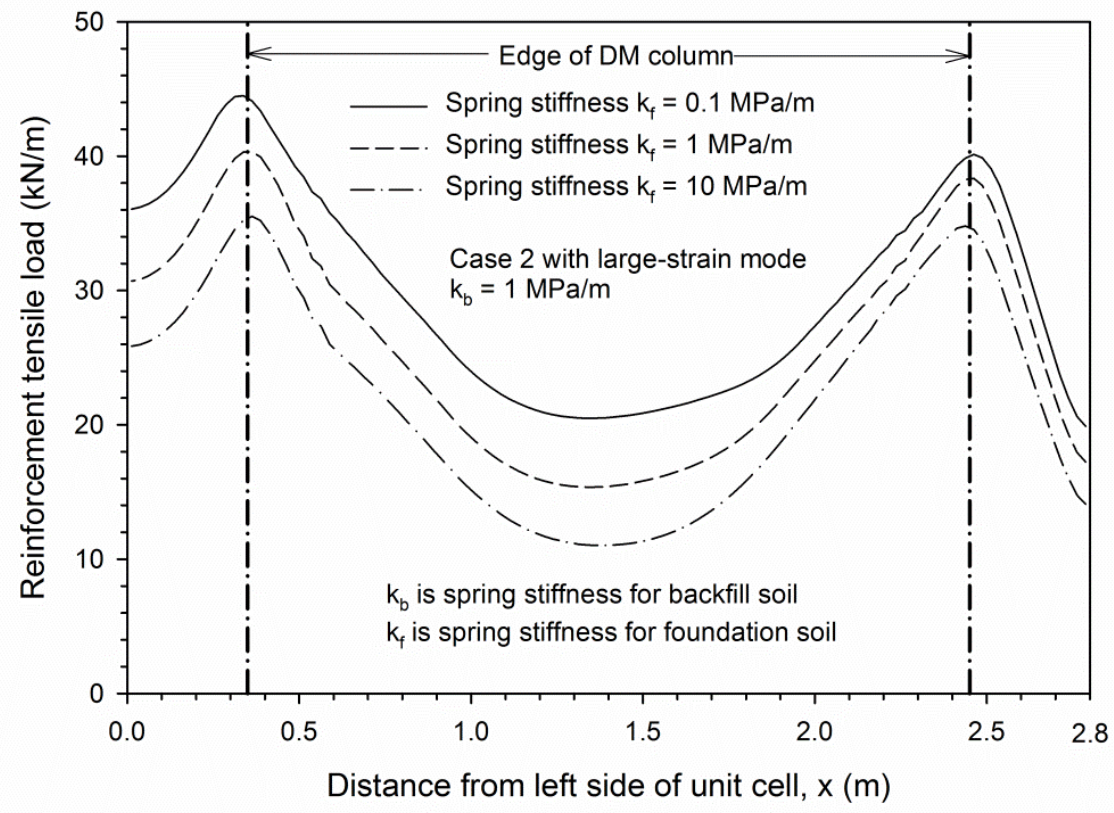

539 Figure 10. Influence of spring stiffness values of the foundation soil for Case 2 unit cell on the reinforcement tensile loads with large-strain mode at 5-m high embankment fill. 


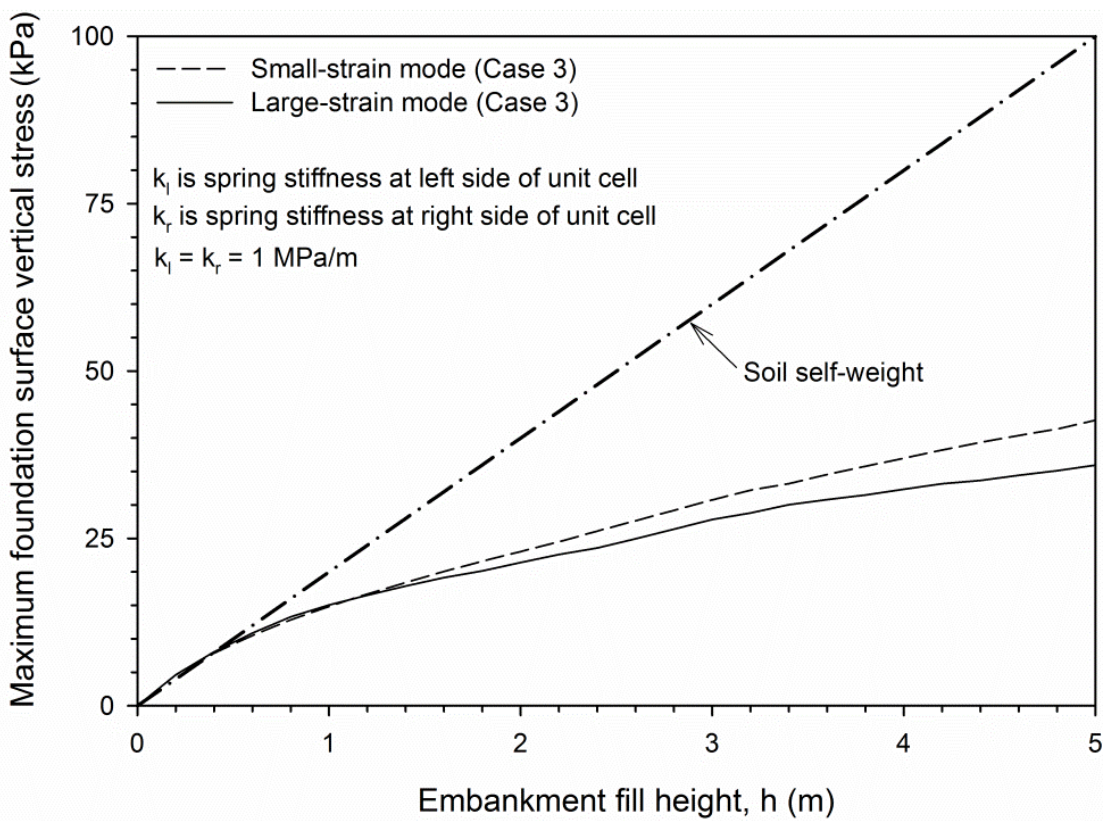

(a)

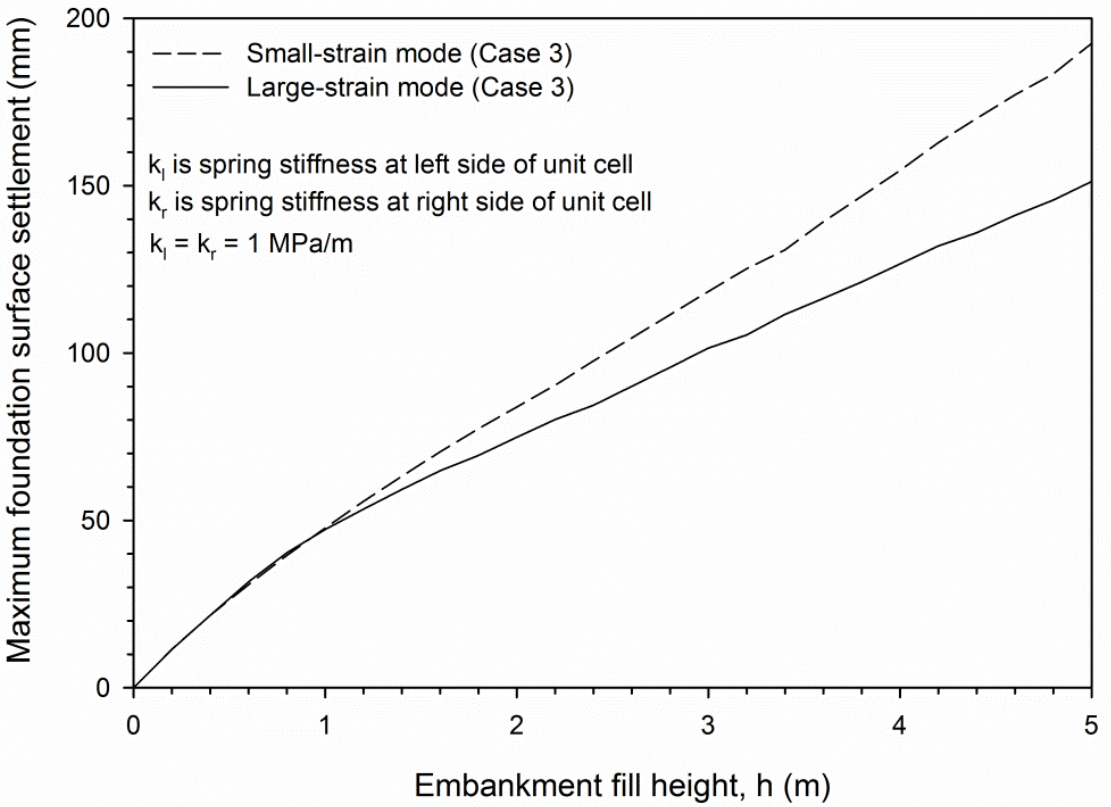

(b)

543 Figure 11. Influence of large- and small-strain mode for Case 3 unit cell with spring stiffness 544 values $k_{1}=k_{\mathrm{r}}=1 \mathrm{MPa} / \mathrm{m}$ on (a) the maximum vertical stresses at the foundation surface, and (b) 545 the maximum settlements at the foundation surface. 


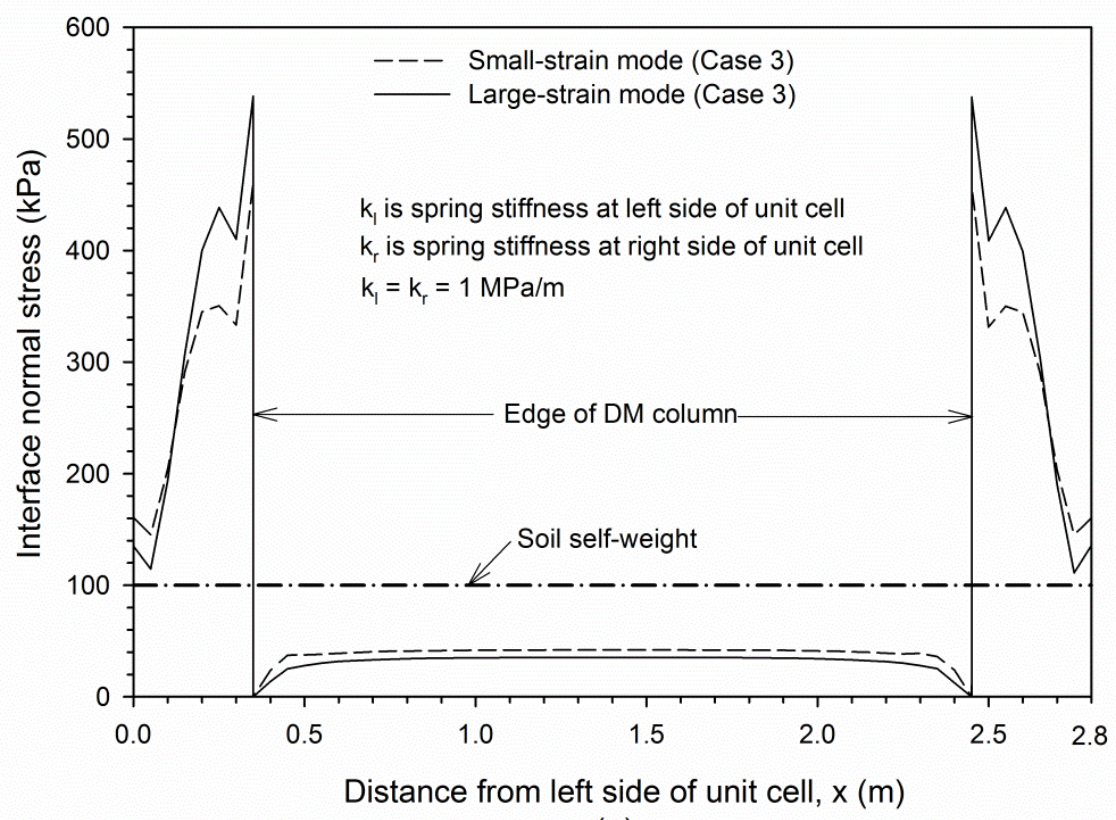

(a)

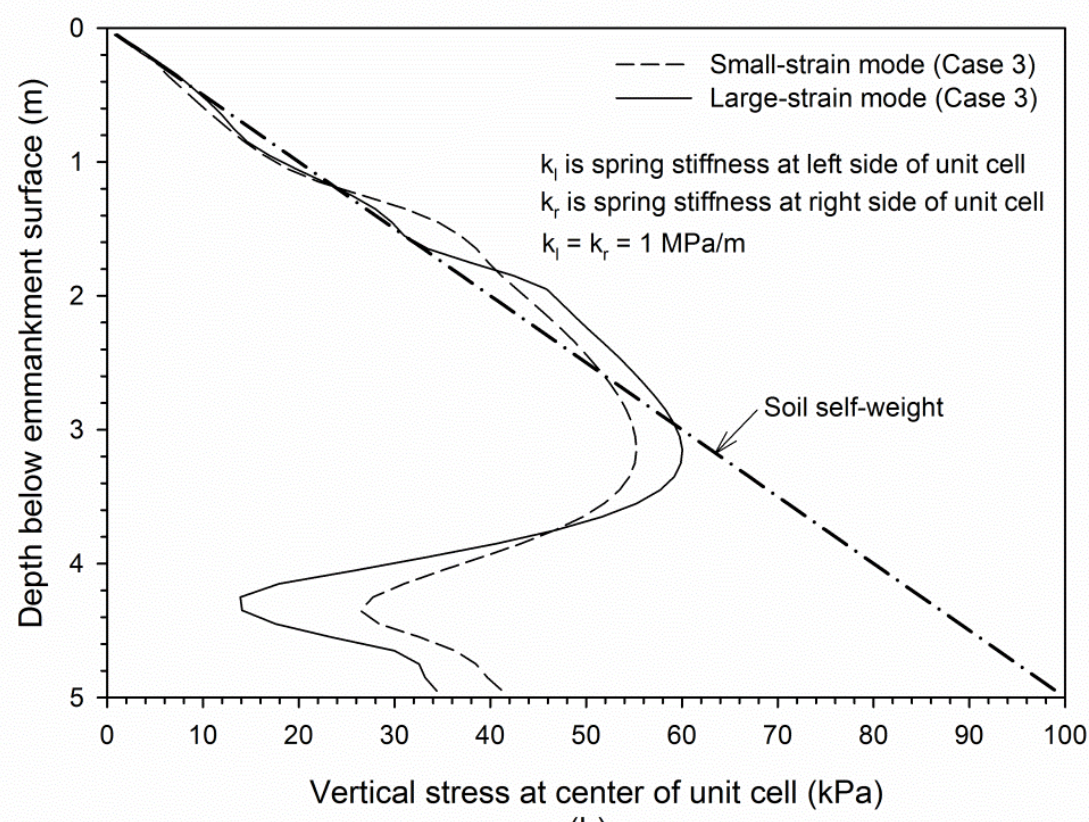

(b)

548 Figure 12. Influence of large- and small-strain mode for Case 3 unit cell with spring stiffness 549 values $k_{1}=k_{\mathrm{r}}=1 \mathrm{MPa} / \mathrm{m}$ on (a) the interface normal stresses at the foundation surface elevation 550 and 5-m high embankment fill, and (b) the vertical stress at the center of unit cell within the 551 embankment fill. 


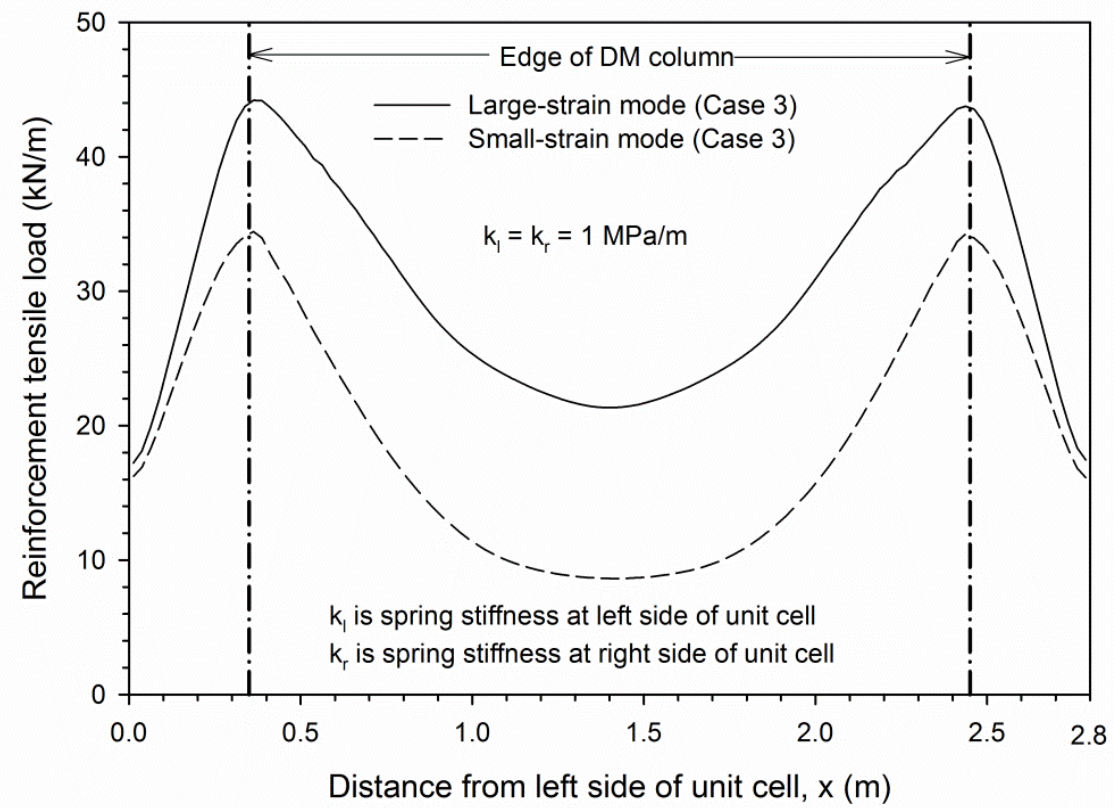

554 Figure 13. Influence of large- and small-strain mode for Case 3 unit cell with spring stiffness values $k_{1}=k_{\mathrm{r}}=1 \mathrm{MPa} / \mathrm{m}$ on the reinforcement tensile loads for 5-m high embankment fill.

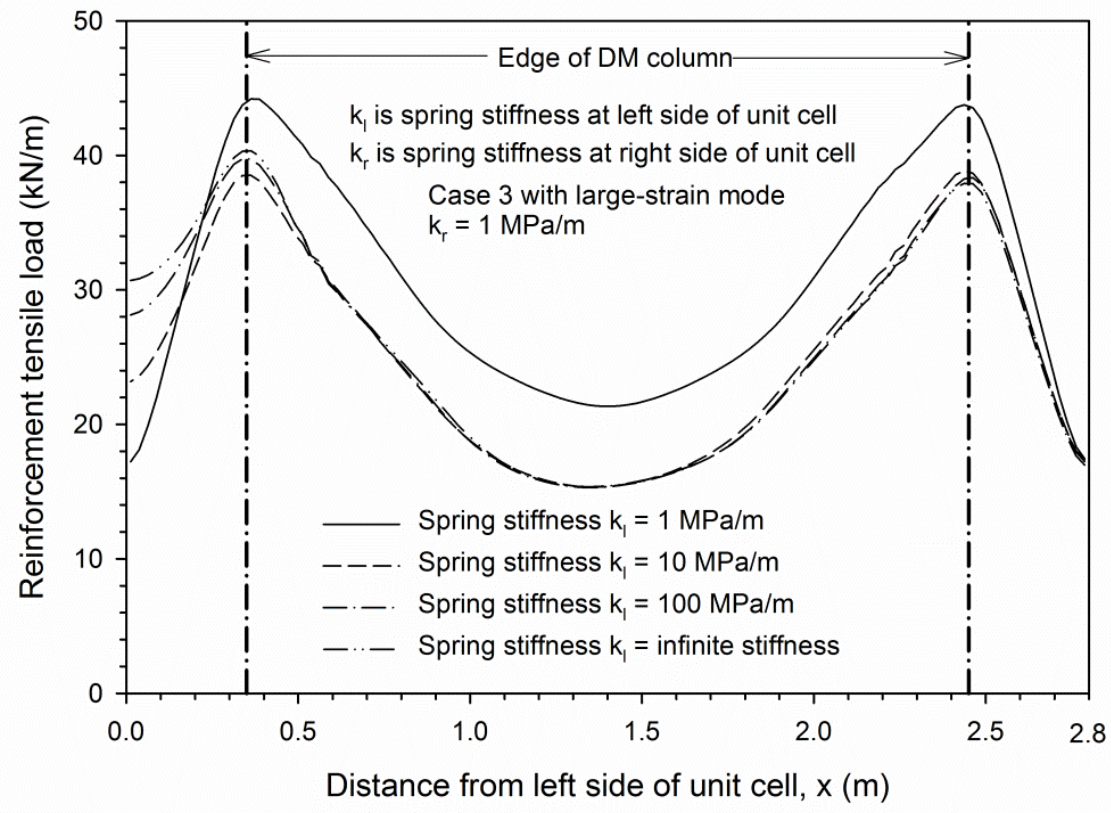

557 Figure 14. Influence of spring stiffness values at left side of Case 3 unit cell on the reinforcement tensile loads with large-strain mode at 5-m high embankment fill using the same spring stiffness values for the embankment fill and foundation soil. 